\title{
외벽조적벽체 연결철물의 내진성능에 관한 실험연구 Experimental Study on the Seismic Capacity of Anchored Brick Veneer on Nonstructural Masonry Walls
}

\author{
오명호* . 김영호** . 정인철*** . 김태희**** . 김명한***** \\ Oh, Myoung Ho*, Kim, Young Ho**, Jung, In Chul***, Kim, Tae Hui****, \\ and Kim, Myeong Han*****
}

\begin{abstract}
The seismic performance of anchored brick veneer with a newly developed tie metal assembly in the nonstructural masonry wall was evaluated experimentally in this study. The test specimens were manufactured with dimensions of $2.2 \mathrm{~m} \times 2.02 \mathrm{~m}$. The experimental variables were the arrangement of the tie metal assembly (orthogonal or staggered), the spacing of the tie metal assembly, and the size of the vertical locking bars. All the test specimens with tie metal assemblies were capable of supporting the equivalent static load based on the Korean Building Code, and retained a drift capacity of more than 2\% corresponding to the performance level of life safety. The vertical locking bars improve the seismic performance of anchored brick veneer moderately, and the recommended spacing of the tie metal assembly is $800 \mathrm{~mm} \times 400 \mathrm{~mm}$.
\end{abstract}

Key words : Nonstructural Masonry Wall, Anchored Brick Veneer, Wall-Tie, Seismic Capacity, Experimental Study

\section{요 지}

이 연구에서는 건축물의 외장재로 널리 사용되는 외벽조적벽체에서 새롭게 개발된 연결철물 상세에 대한 내진성능을 실험적으로 평가하였다. 실험체의 크기는 $2.2 \mathrm{~m} \times 2.02 \mathrm{~m}$ 이고, 주요 실험변수로는 연결철물의 배치방법(정렬배치, 엇모배치)과 연결철물의 보강간격 및 수직 록킹 바의 크기이다. 실험결과 연결철물을 설치한 모든 실험체가 국내건축기준에 의한 등가정적횡하중 이상을 지지할 수 있으며, $2 \%$ 이상의 횡변위각 성능을 발휘하여 인명안전의 성능수준을 만족하고 있음을 확인하였다. 또한 수직 록킹 바는 외벽조적벽체의 내진성능을 향상시키며, 연결철물의 간격은 $800 \mathrm{~mm} \times 400 \mathrm{~mm}$ 으로 하는 것이 바람직하다.

핵심용어 : 비구조 외벽조적벽체, 매입형 치장벽체, 연결철물, 내진성능, 실험연구

\section{1. 서 론}

건축물의 외벽마감에 사용되는 벽돌은 오랜 기간 동안 광범위하게 사용되는 건축 재료이고, 건축 설계 상의 요구에
부응하여 형상, 흡수율, 모듈, 질감, 색상이 다양한 건축용 벽돌이 개발되었다. 외벽 마감용 벽돌은 $20 \sim 25 \%$ 정도의 함수율을 갖는 점토를 진공 성형하여 터널요에서 1,200 $1,350 \mathrm{oC}$ 로 소성하여 제품화한 것으로 형상은 일반형, 유공

*정회원, 국립목포대학교 건축공학과 교수(E-mail: ohmho@mokpo.ac.kr)

Member, Professor, Department of Architectural Engineering, Mokpo National University

**정회원, (주)엔테이지 대표(E-mail: steelkyh@hanmail.net)

Member, President, NTAGE

***정회원, 세라코 이사(E-mail: icjung@dongaceramic.com) Member, Director, CERACO

****국립목포대학교 건축공학과 교수(E-mail: thkim@mokpo.ac.kr)

Professor, Department of Architectural Engineering, Mokpo National University

*****교신저자, 정회원, 국립목포대학교 건축공학과 교수(Tel: +82-61-450-2456, Fax: +82-61-450-6454, E-mail: mhk314@mokpo.ac.kr)

Corresponding Author, Member, Professor, Department of Architectural Engineering, Mokpo National University 
형, 공동형이 있으며, 표준 치수는 $190 \times 90 \times 57 \mathrm{~mm}$ 이다. 재질감이 우수한 벽돌은 주로 학교, 종교시설, 관공서 등에서 많이 사용하고 있으나, 비구조재로 사용되기 때문에 지진 발생 시 큰 손상으로 인해 경제적 손실뿐만 아니라 인명 피해도 발생할 수 있다. 따라서 치장 조적벽체와 같은 비구조 요소에 대해서 지진과 같은 수평력에 대해 구체적인 대책 마련과 보강 기법 수립이 필요하다.

건축 구조물에 대한 내진 설계는 기둥, 보 그리고 내력벽 등과 같은 주요 구조 요소에서는 적용이 강화되고 있는 반면에 비구조요소에 대한 내진설계는 상대적으로 소홀히 다루어지고 있다. 특히 건축물의 마감용도로 널리 사용되는 치장 조적벽체의 경우는 현장 조적 인부의 경험에 좌우되는 등 시공완성도의 차이도 또한 매우 상이하다. 따라서 비구조 재로 사용되는 외벽 조적마감 벽체의 경우, 지진이 발생하면 내력벽과의 결합력이 상실되면서 균열, 탈락 등이 발생하기 쉽기 때문에 건축구조기준(KBC, 2016)에서는 비구조 요소 에 대한 내진설계기준이 제시되었다. 하지만 비구조요소에 대한 상세와 보강법은 제시되어 있지 않다(Jin et al., 2008). 건축 구조물의 내진 보강 및 설계에 있어서 수평내력과 연성능력은 구조요소의 내진성능을 결정하는 가장 중요한 요인이다. 따라서 내진성능을 향상시키기 위해서는 구조요 소의 수평내력 증대, 연성능력 향상으로 정의할 수 있다. 조적벽체 역시 수평내력 증대와 연성능력 확보로 내진 보강 할 수 있다. 현재까지 국내외 여러 연구에 의하면, 내력벽으로 사용되는 조적벽체에 대한 연구결과들은 축적되어 있으나 비구조요소로 사용되는 외벽 치장 벽체에 대한 연구는 매우 부족한 실정이다(Yi et al., 2004; Park and Kwon, 2015). 해외에서는 구조벽체와 치장벽체 사이에 다양한 연결철물 을 이용하여 치장벽체를 구조벽체에 지지하여 외력에 대한 안정성을 확보하도록 하였고, 치장조적조의 줄눈에 철선을 매입하여 개체탈락을 방지하도록 하고 있다(Jin et al., 2008;

Martins et al., 2017).

따라서 본 연구에서는 건축물의 외장재로 널리 사용되고 있는 치장조적벽체에서 새롭게 개발한 연결철물 상세에 대한 내진성능을 준정적실험을 통해 분석하고자 한다.

\section{2. 실험 계획}

\section{1 실험체 계획}

외벽조적치장벽체와 내진보강 연결철물을 사용하여 시 공된 조적치장벽체에 면내하중을 가하는 준정적실험을 통 해 조적치장벽체의 내진성능을 분석하였다. 실험체에 사용 된 연결철물 상세는 Fig. 1과 같다.

제안된 연결 철물 상세는 수직 록킹 바(Locking bar)를 이용하여 상부 및 하부 벽돌을 상호 묶어서 일체로 작용하게 하여 조적벽체에 지진에 의한 전도 모멘트 발생 시 내진 저항성을 극대화시킬 수 있는 방법으로 고안되었다.
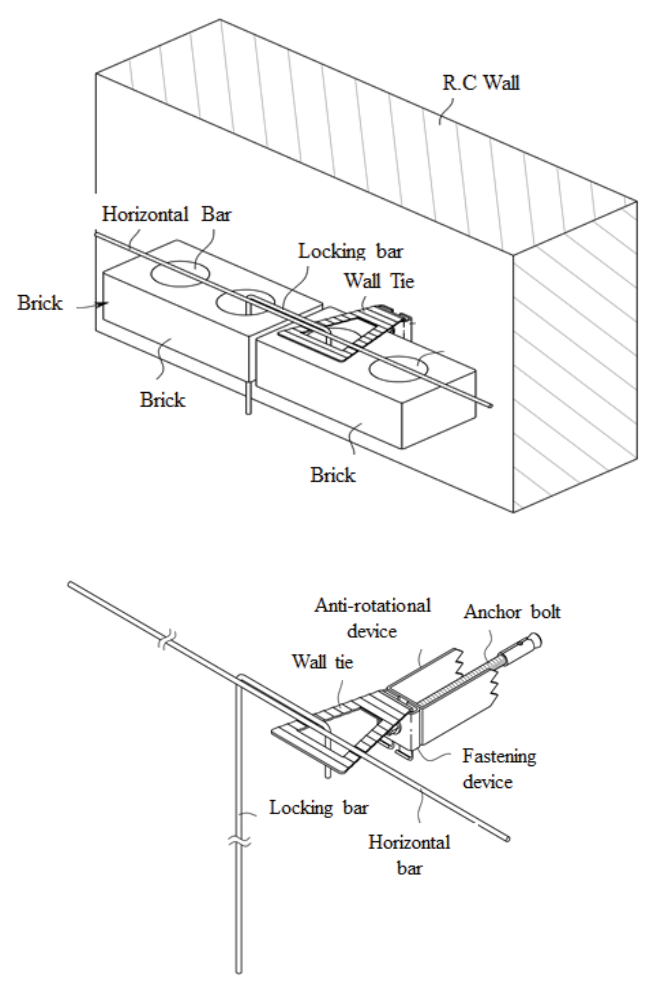

Fig. 1. The Details of Wall Tie using the Locking Bar

실험체는 $2.2 \mathrm{~m} \times 2.02 \mathrm{~m}$ 크기로 제작하였으며, 주요 실험변수는 연결철물의 배치방법, 즉 정렬배치 $(\mathrm{L})$ 와 엇모배 치(Z)과 연결철물의 보강간격 $(800 \mathrm{~mm} \times 400 \mathrm{~mm}, 800 \mathrm{~mm}$ $\times 600 \mathrm{~mm})$ 및 수직 록킹 바의 크기 $(\phi 3, \phi 6)$ 로 구성하였다. 조적치장벽체는 수직 압축력으로 벽체 자중만을 고려하므 로 축방향 압축력은 변수에서 제외하였다.

모든 실험체는 외벽마감을 구성하는 치장벽체로써 철근 콘크리트 벽체에 연결철물을 이용하여 $0.5 \mathrm{~B}$ 쌓기로 구성되 어 있다. 한편 치장벽체를 연결철물로 정착되는 철근콘크리 트 내력벽체를 제작하였으며, 이러한 철근콘크리트 내력벽 체는 $0.5 \mathrm{~B}$ 쌓기의 치장벽체에서 전달되는 하중에 의하여 손상을 방지하기 위해 충분한 강도를 갖도록 설계하였다.

또한 연결철물의 보강간격은 BIA (2003)에서 제시한 대로 최대수직간격은 $18 \mathrm{in} .(457 \mathrm{~mm})$, 최대수평간격은 32in. (813 $\mathrm{mm})$ 을 참조하여 기본 간격은 $800 \mathrm{~mm}\left(s_{h}\right) \times 400 \mathrm{~mm}\left(s_{v}\right)$ 으로 설정하였고, 국내 시공 실정을 고려하여 수직간격 $\left(s_{v}\right)$ 을 늘린 $800 \mathrm{~mm}\left(s_{h}\right) \times 600 \mathrm{~mm}\left(s_{v}\right)$ 을 실험변수에 추가하여 보강간격 의 효과를 살펴볼 수 있도록 계획하였다. 또한 연결철물의 두께 $(t)$ 는 $2.0 \mathrm{~mm}$ 로 하였고, 단열재의 두께는 $150 \mathrm{~mm}$ 로 계획 하여 시공하였다.

수직 록킹 바의 직경은 $3 \mathrm{~mm}$ 를 기본으로 하여 벽돌 4장이 묶일 수 있도록 계획하였으며, 록킹 바를 설치하지 않은 것과 $6 \mathrm{~mm}$ 를 추가로 계획하여 수직 록킹 바의 효과를 분석하 였다. 이러한 실험체의 상세는 Fig. 2에 나타내었고 실험체 일람은 Table 1에 정리하였다. 


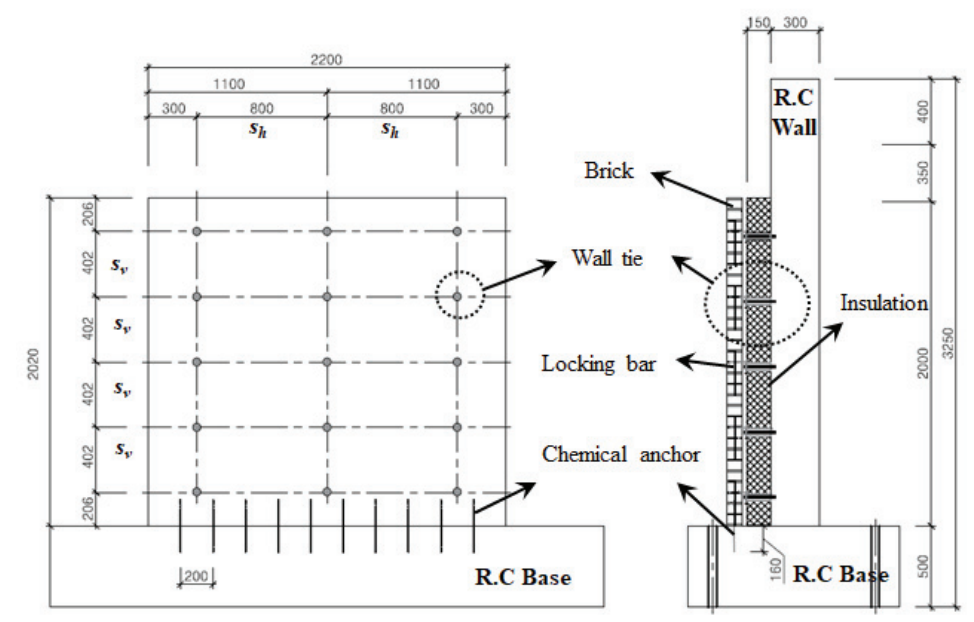

(a) Line Arrangement

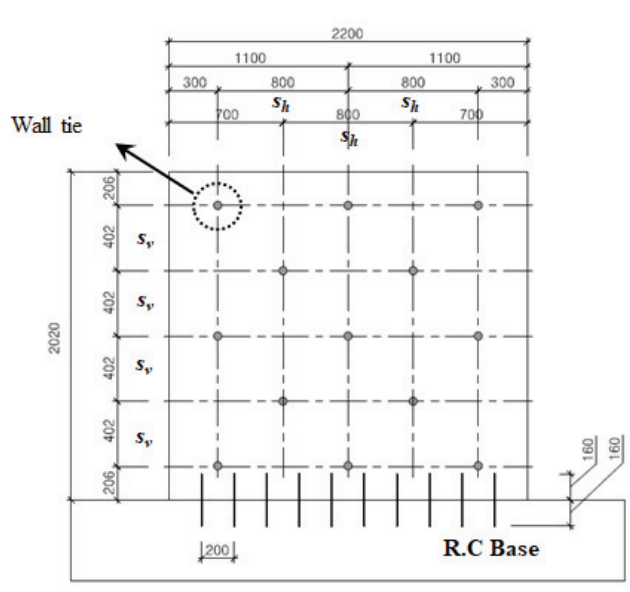

(b) Zigzag Arrangement

Fig. 2. The Details of Wall Tie Arrangement

Table 1. Test Specimens

\begin{tabular}{c|c|c|c|c|c|c|c}
\hline \multirow{2}{*}{$\begin{array}{c}\text { Specimens } \\
\text { ID }\end{array}$} & \multirow{2}{*}{$\begin{array}{c}\text { Arrangement } \\
\text { of Wall tie }\end{array}$} & $\begin{array}{c}\text { Horizontal } \\
(\mathrm{mm})\end{array}$ & $\begin{array}{c}\text { Vertical } \\
(\mathrm{mm})\end{array}$ & $\begin{array}{c}\text { Space of Wall Tie } \\
\text { Horizontal bar } \\
(\mathrm{mm})\end{array}$ & $\begin{array}{c}\text { Size of Vertical } \\
\text { Locking bar } \\
(\mathrm{mm})\end{array}$ & $\begin{array}{c}\text { Thickness of } \\
\text { Insulation } \\
(\mathrm{mm})\end{array}$ \\
\hline 1 & EML-S600-L3-I & Line & 800 & 600 & $\phi 3$ & $\phi 3$ & 150 \\
\hline 2 & EMZ-S400-L3-I & Zigzag & 800 & 400 & $\phi 3$ & $\phi 3$ & 150 \\
\hline 3 & EML-S400-L6-I & Line & 800 & 400 & $\phi 3$ & $\phi 6$ & 150 \\
\hline 4 & EML-S400-L3-I & Line & 800 & 400 & $\phi 3$ & $\phi 3$ & 150 \\
\hline 5 & EML-S400-L×-I & Line & 800 & 400 & $\phi 3$ & $\times$ & 150 \\
\hline 6 & EML-S400-L3-× & Line & 800 & 400 & $\phi 3$ & $\phi 3$ & $\times$ \\
\hline
\end{tabular}

1) $\operatorname{EML}(Z)$ : Earthquake Masonry Line (Zigzag)

3) L3(6 or $\times)$ : Size of Vertical Locking bar
2) S600(400): Vertical Space of Wall Tie

4) $I(\times)$ : Insulation

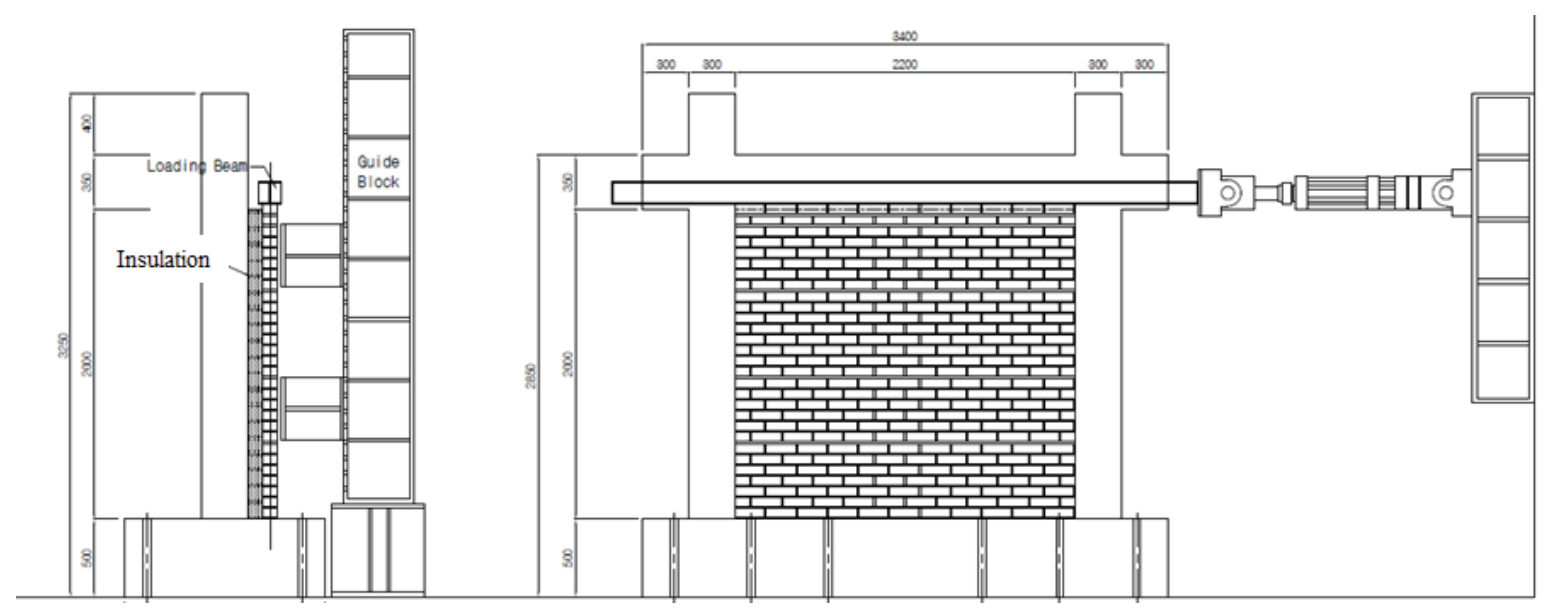

Fig. 3. Setting Plan of Specimen

\section{2 가력 방법}

본 실험은 대우건설기술연구원 대형구조실험동에서 300 $\mathrm{kN}$ 의 액츄에이터를 사용하였다. 실험체의 상부에 $\mathrm{H}-200$ $\times 200 \times 8 \times 12$ 의 가력용 철골 보를 에폭시 접착하여 설치하였 으며, 실험체의 횡변위는 가력 보의 중앙부에서 측정하였다. 이러한 실험체 세팅도를 Fig. 3에 나타내었다. 
하중가력은 변위제어방식을 적용하였으며 가력 보를 기 준으로 조적벽체 상단에 하중이 도입되도록 하였으며, 하중 단계별로 2회씩 반복 가력 하였다. 이러한 실험체 가력 계획 은 Fig. 4에 나타내었다(Jin et al., 2008).

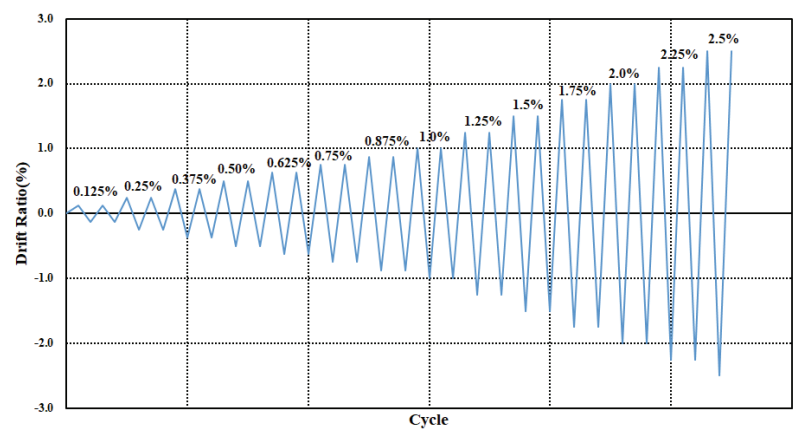

Fig. 4. Loading Plan

\section{3 측정 방법}

실험체의 측정 계획은 Fig. 5와 같다. 가력에 따른 실험체의 미끄러짐을 보정하기 위하여 하단에 LVDT-12를 설치하였 고, 조적벽체의 상하단의 수평변형을 측정하기 위하여 상단 에는 LVDT-2, LVDT-3을 설치하였으며, 하단에는 LVDT-8 과 LVDT-9를 설치하였다.

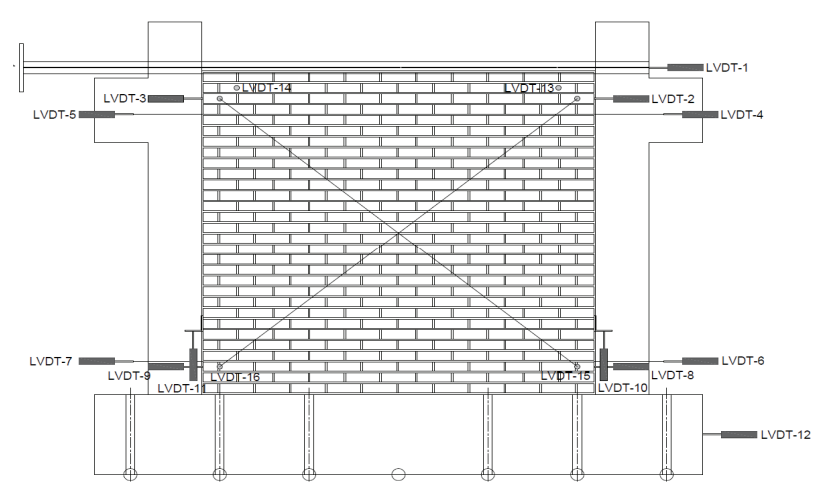

Fig. 5. Installation Plan of LVDT

또한 하단에서 조적벽체의 들뜸은 LVDT-10과 LVDT-11을 통해 측정하였으며, 조적벽체가 지지되는 반력벽과 벽체 사이 에 연결된 연결철물의 변형량을 측정하기 위하여 LVDT-4, $5,6,7$ 을 설치하였다. 그리고 조적벽체의 전단변형을 측정하기 위하여 LVDT-15, 16을 설치하였고, 가력에 따른 조적벽체의 면외방향 이탈을 측정하기 위하여 LVDT-13과 LVDT-14를 가력부 하단에 설치하여 측정하였다.

\section{3. 실험 결과 및 분석}

\section{1 재료 시험}

조적개체 압축강도, 모르타르 압축강도, 프리즘 압축강도,
그리고 사인장 전단강도 등에 대한 재료시험을 Fig. 6과 같이 수행하였다.

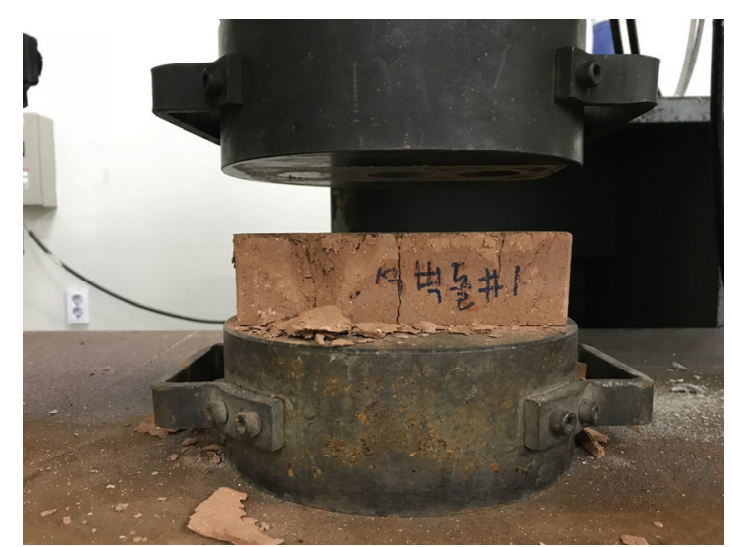

(a) Compression Test of Brick

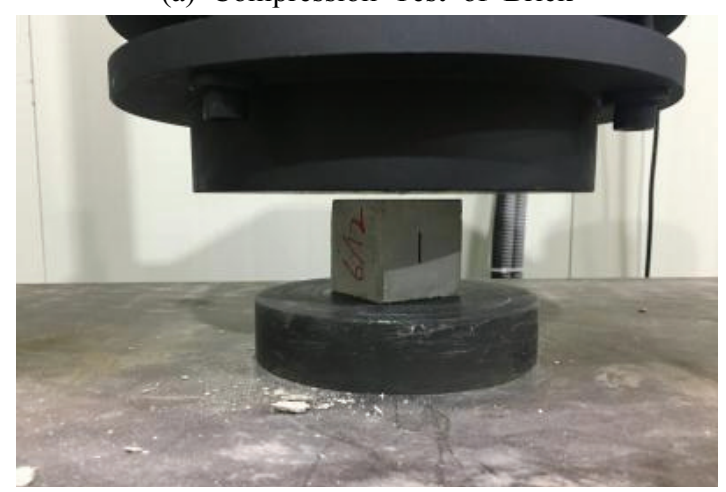

(b) Compression Test of Mortar

Fig. 6. Material Test

조적개체 압축강도 시험에 사용된 조적개체의 형상은 $190 \times 90 \times 57 \mathrm{~mm}$ 으로 3 개 제작하여 시험을 수행하였으며 평균값은 $26.23 \mathrm{MPa}$ 이다. $\mathrm{KS} \mathrm{L} \mathrm{4201(점토벽돌,} \mathrm{2017)에} \mathrm{의하}$ 면 점토벽돌의 압축강도는 1 종(내장재 및 외장재) $24.50 \mathrm{MPa}$, 2종(내장재) $14.70 \mathrm{MPa}$ 이상으로 규정하고 있다.

모르타르 공시체 제작에 있어서, KS L 5105 (2007) 기준의 경우 무게 배합비 $1: 2.45$, 혼합수의 양은 시멘트 무게의 $48.5 \%$, 플로(Flow)는 $110 \pm 5(\%)$, 그리고 공시체의 습윤 양생 을 제시하고 있다.

모르타르 압축강도 시험편은 실제 조적 벽체 시험체 제작 에 사용된 조적용 레미탈로 $50 \times 50 \times 50 \mathrm{~mm}$ 크기로 제작하였 으며, 28 일 기건 양생 후에 모르타르 압축강도 시험을 수행하 였다. 그 결과 평균값은 $13.4 \mathrm{MPa}$ 이다. 국내에서는 $\mathrm{KS} \mathrm{L}$ 5220(건조 시멘트 모르타르, 2018)에서 조적용 모르타르의 28 일 강도에 대하여 $11 \mathrm{MPa}$ 이상으로 규정하고 있다.

또한 실험체에 사용된 강선의 직경은 약 $3.75 \mathrm{~mm}$ 로 수평 철근과 수직 록킹 바에 사용되었다. 이 강선의 인장시험결과, 항복강도 $\left(F_{y}\right)$ 는 $644 \mathrm{MPa}$ 이고 인장강도 $\left(F_{u}\right)$ 는 $717 \mathrm{MPa}$ 이다. 탄성계수는 $194 \mathrm{GPa}$, 연신률은 $19 \%$ 로 측정되었다. 


\section{2 균열 및 파괴 양상}

외장조적벽체의 준정적실험체는 일반적으로 $0.5 \mathrm{~B}$ 쌓기 의 조적치장벽체로서 벽체 두께가 매우 얇아 모르타르와 조적개체와의 접착력이 크지 않으므로, 기초 상단에서 200 $\mathrm{mm}$ 부근(벽돌 2 3단 위치)의 수평 줄눈에서 균열이 발생하 였으며, 동일한 위치에서 균열 폭의 증가와 균열이 진전되는 양상을 보였다.

EML-S600-L3-I 실험체는 Step $1(0.125 \%)$ 정가력에서 벽체 중앙부에서 벽돌에 균열이 발생하였으며, 부가력에서 는 중앙 하단에서 모르타르와 벽돌 계면에서 균열이 발생하 였다. 이하 변위가 증가함에 따라 조적벽체 면에서의 균열이 확대되고, 벽체 단부쪽에서 수직균열이 발생함에 따라 벽돌 이 쪼개짐이 발생하는 등 변형이 증가하였다(Fig. 7(a) 참조).

EML-S600-L3-I 실험체를 제외한 모든 실험체는 Fig. 7(b) 에서 보는 바와 같이 기초 상단에서 $200 \mathrm{~mm}$ 부근에서 줄눈 모르타르가 미끄러짐(Bed Joint Sliding)이 발생하였으며, 이후 동일한 위치에서 수평 줄눈의 균열이 폭이 확대되어 수평력을 지지하였다. 이는 연결철물의 수직 간격이 좁아지 면 조적벽 개체 사이의 부착력이 증가되고 이에 따라 수평하 중이 가장 집중되는 벽체 하단부에서 가장 약한 부분인 줄눈 모르타르에서 먼저 균열이 발생되기 때문이다. 전단거 동에 영향을 주는 자중 이외 축방향 압축력이 없으므로 사인장 균열은 거의 발생하지 않았다.

\section{3 하중-변위각 관계}

각 실험체별 하중(Lateral Load)-변위각(Drift ratio) 곡선 을 Fig. 8에 나타내었다. 단열재 $150 \mathrm{~mm}$ 을 설치하지 않은 실험체(EML-S400-L30-×)를 제외하고 모든 실험체는 Step $1(0.125 \%)$ 정가력 시 모르타르 줄눈에서 균열이 발생하여 항복 하중 $\left(P_{y}\right)$ 에 도달하였고, 이 때의 변위를 항복 변위 $\left(\Delta_{y}\right)$

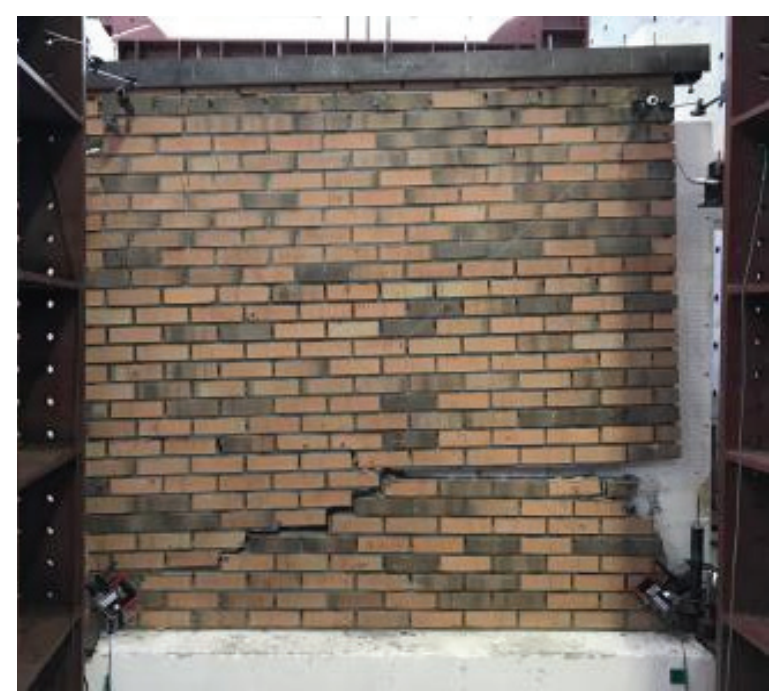

(a) Crack Pattern of EML-S600-L3-I
로 정의하였다. 이 후 부가력에서는 조적벽에 균열이 발생하 였으므로 강성과 강도가 정가력 때보다 상대적으로 낮았다. 그 이후 Step $2(0.25 \%)$ 에서는 변위가 증가함에 따라 조적벽 체의 강성과 강도가 감소하였지만, Step $3(0.375 \%)$ 이후에서 는 강성은 줄어들지만, 강도는 증가하는 양상을 보였다.

단열재를 설치하지 않은 실험체(EML-S400-L30-×)에서 는 Step $1(0.125 \%)$ 정가력 시 모르타르 줄눈에 균열이 발생하 였음에도 Step 2 이후에서도 강도가 증가하고 있는 것을 알 수 있다. 단열재를 설치하지 않은 실험체에서는 연결철물 의 길이가 다른 실험체에 비해 상대적으로 짧아 연결철물의 강도가 조적벽체의 강도에 기여한 결과로 판단된다.

모든 실험체가 목표로 하는 변위각 $2 \%$ 이상을 달성하였으며 각 실험체별로 최종 변위각에서의 하중 및 변위를 최종 강도 $\left(P_{R}\right)$ 와 최종 변위 $\left(\Delta_{R}\right)$ 로 정의 하여 Table 2 에 나타내었다.

연결철물을 설치하지 않은 실험체에서는 변위각 $1.5 \%$ 에 서 갑작스럽게 면외방향으로 전도하는데, 이는 추가적인 수직하중이 존재하지 않고 벽체 두께가 매우 세장하므로, 강체회전 부위의 균열이 발생하여 종국적으로 구조적 안전 성을 잃고 갑작스런 면외-전도 파괴가 일어난 것으로 보고한 바 있다(Jin et al., 2008).

연결철물의 수직 간격 $\left(s_{v}\right)$ 이 $600 \mathrm{~mm}$ 와 $400 \mathrm{~mm}$ 로 서로 다른 실험체 EML-S600-L3-I와 EML-S400-L3-I의 실험결과 를 Table 2 및 Fig. 8에서 살펴보면, 정가력 시 항복하중 $\left(P_{y^{+}}\right)$ 은 각각 $12.5 \mathrm{kN}$ 과 $18.0 \mathrm{kN}$ 이고, 최종강도 $\left(P_{R+}\right)$ 는 $14.0 \mathrm{kN}$ 과 $17.6 \mathrm{kN}$ 으로 수직 간격이 좁은 실험체가 더 좋은 저항 성능을 보이고 있다.

또한 수직 록킹 바의 크기가 서로 다른 실험체 EML-S400-L6-I, EML-S400-L3-I 및 EML-S400-L×-I의 실험결과를 살펴보면, 정 가력 시 항복하중 $\left(P_{y+}\right)$ 은 록킹 비의 크가가 클수록 크지만, 최종강 도 $\left(P_{R+}\right)$ 는 록킹 바의 크기가 작을수록 큰 경향을 보이고 있다.

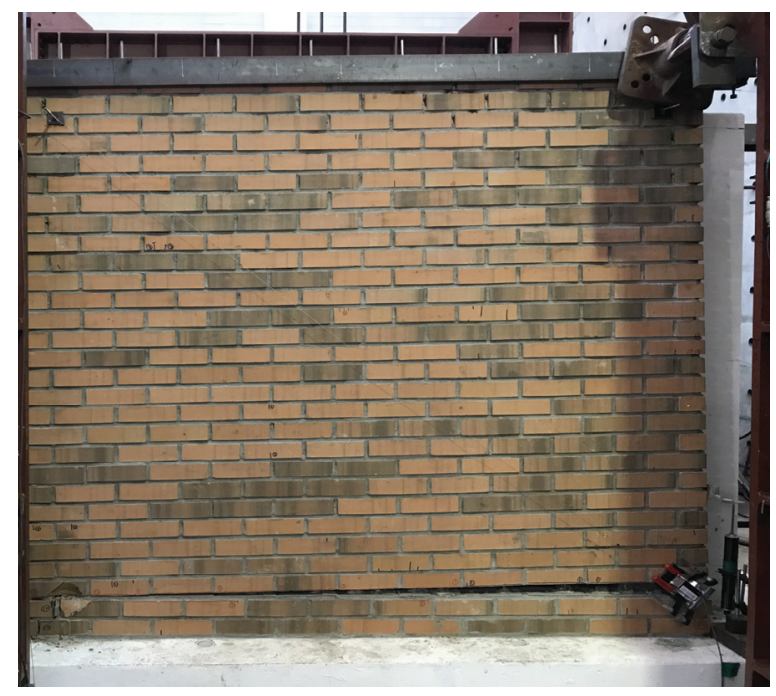

(b) Crack Pattern of EML-S400-L3-I

Fig. 7. Failure Mode of Specimens 


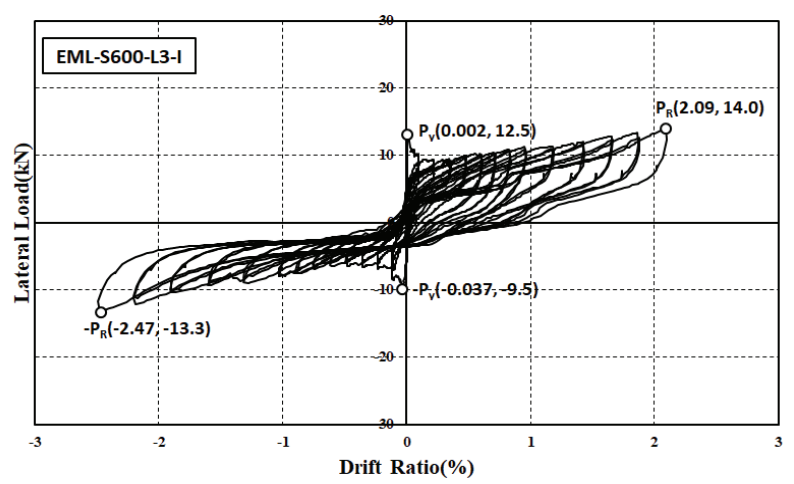

(a) EML-S600-L3-I

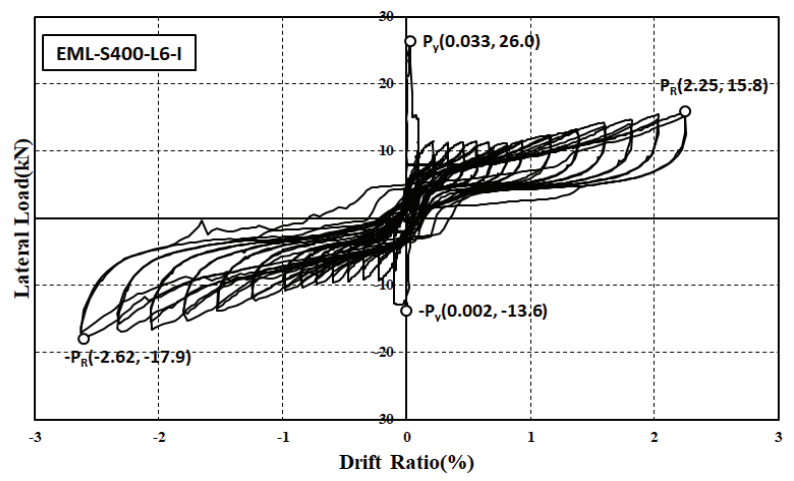

(c) EML-S400-L6-I

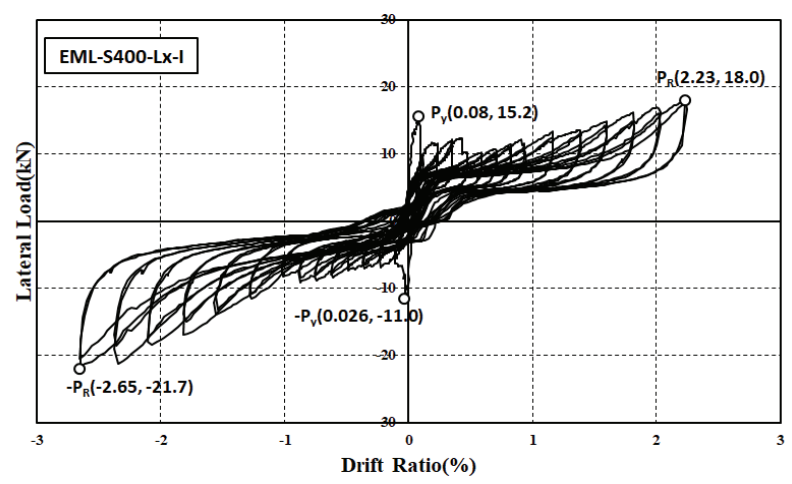

(e) EML-S400-L×-I

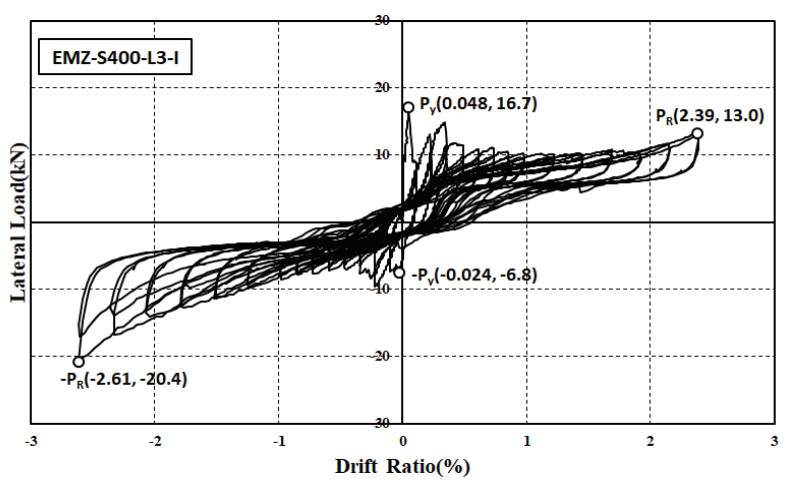

(b) EMZ-S400-L3-I

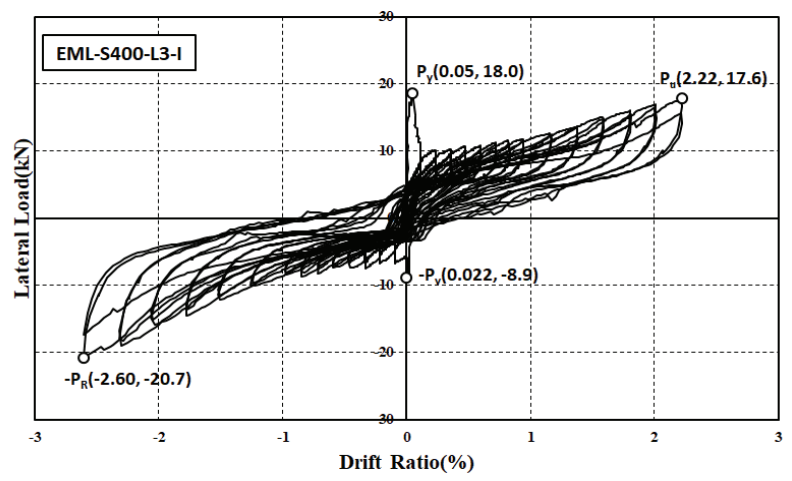

(d) EML-S400-L3-I

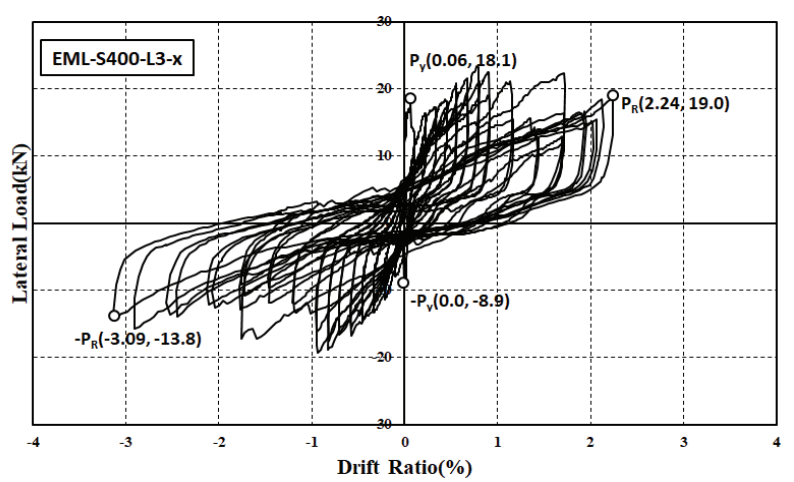

(f) EML-S400-L3-×

Fig. 8. The Load-Displacement Curve

Table 2. Test Results

\begin{tabular}{c|c|c|c|c|c|c|c|c}
\hline $\begin{array}{c}\text { Specimens } \\
\text { ID }\end{array}$ & $\begin{array}{c}\mathrm{P}_{\mathrm{y}^{+}} \\
(\mathrm{kN})\end{array}$ & $\begin{array}{c}\mathrm{P}_{\mathrm{y}-} \\
(\mathrm{kN})\end{array}$ & $\begin{array}{c}\Delta_{\mathrm{y}^{+}} \\
(\mathrm{mm})\end{array}$ & $\begin{array}{c}\Delta_{\mathrm{y}-} \\
(\mathrm{mm})\end{array}$ & $\begin{array}{c}\mathrm{P}_{\mathrm{R}+} \\
(\mathrm{kN})\end{array}$ & $\begin{array}{c}\mathrm{P}_{\mathrm{R}-} \\
(\mathrm{kN})\end{array}$ & $\begin{array}{c}\Delta_{\mathrm{R}+} \\
(\mathrm{mm})\end{array}$ & $\begin{array}{c}\Delta_{\mathrm{R}-} \\
(\mathrm{mm})\end{array}$ \\
\hline EML-S600-L3-I & 12.5 & 9.5 & 0.05 & 0.85 & 14.0 & 13.3 & 48.2 & 56.9 \\
\hline EMZ-S400-L3-I & 16.7 & 6.8 & 1.10 & 0.55 & 13.0 & 20.4 & 54.9 & 60.1 \\
\hline EML-S400-L6-I & 26.0 & 13.6 & 0.75 & 0.05 & 15.8 & 17.9 & 51.8 & 60.2 \\
\hline EML-S400-L3-I & 18.0 & 8.9 & 1.25 & 0.50 & 17.6 & 20.7 & 51.0 & 59.9 \\
\hline EML-S400-L×-I & 15.2 & 11.0 & 1.85 & 0.60 & 18.0 & 21.7 & 51.3 & 60.9 \\
\hline EML-S400-L3-× & 18.1 & 8.9 & 1.4 & 0.00 & 19.0 & 13.8 & 51.6 & 71.1 \\
\hline
\end{tabular}


마지막으로 연결철물의 배치를 정렬배치(L) 또는 엇모 배치(Z)의 경우의 실험체 EMZ-S400-L3-I 및 EML-S400$\mathrm{L} 3-\mathrm{I}$ 의 실험결과를 살펴보면, 연결철물이 정렬배치된 실 험체가 항복강도 $\left(P_{y+}\right)$ 와 최종강도 $\left(P_{R+}\right)$ 가 더 큼을 알 수 있었다.

\section{4 외벽조적치장벽체의 내진성능평가}

비구조요소에 대한 국내의 내진설계기준은 건축구조기 준 $(\mathrm{KBC}, 2016)$ 에 다음의 Eq. (1)과 같이 규정된 등가정적하 중 $\left(F_{p}\right)$ 을 견디도록 되어 있다(MOLIT, 2016).

$$
F_{p}=\frac{0.4 a_{p} S_{D S} W_{p}}{\left(\frac{R_{p}}{I_{p}}\right)}\left(1+2 \frac{z}{h}\right)
$$

단, $F_{p}$ 는 다음의 값을 초과할 필요는 없다.

$$
F_{p}=1.6 S_{D S} I_{p} W_{p}
$$

그러나 $F_{p}$ 는 다음의 값 이상이 되어야 한다.

$$
F_{p}=0.3 S_{D S} I_{p} W_{p}
$$

여기서, $a_{p}$ : 증폭계수 $(=1.0$, 표면마감재 중 변형성능이 낮은 부재 및 부착물), $F_{p}$ : 비구조요소 질량 중심에 작용하 는 설계지진력, $I_{p}$ : 비구조요소의 중요도계수 $(=1.0), h$ : 구조물의 밑면으로부터 지붕층까지의 평균높이 $(=2 \mathrm{~m})$, $R_{p}$ : 비구조요소의 반응수정계수 $(=1.25$, 표면마감재 중 변형성능이 낮은 부재 및 부착물), $S_{D S}$ : 단주기에서의 설계스펙트럼가속도(지진구역 I $S=0.22$, 지반종류 $S_{D}$ 가정), $W_{p}$ : 비구조요소의 가동중량 $(=4.5 \mathrm{kN}$, 벽돌 1 매의 무게 $15 \mathrm{~N}), z$ : 구조물의 밑면으로부터 비구조요소가 부착 된 높이 $(=2 \mathrm{~m})$

이러한 국내건축구조기준(KBC 2016)을 이용하여 본 실 험체가 부담하여야 할 등가정적횡하중 $\left(F_{p}\right)$ 의 크기는 $2.4 \mathrm{kN}$ 이다. Table 2 와 Fig. 8 에서 보는 바와 같이 모든 실험체는 국내건축구조기준에서 요구하는 등가정적횡하중을 만족하 고 있음을 알 수 있다.

또한 FEMA273에서는 건축 비구조요소인 외장재 중 매입형 치장벽체(Anchored Veneer)의 성능수준에 대한 한계상태를 횡변위로 규정하고 있는데 즉시거주(Immediate Occupancy, IO) 성능수준은 $1 \%$ 로 인명안전(Life Safety, LS) 성능수준은 $2 \%$ 로제시하고 있다(FEMA, 1997). Fig. 8에서 나타낸 바와 같이 모든 실험체는 $2 \%$ 이상의 횡변위각 성능을 발휘하여 인명안전(LS)의 성능 수준을 만족하고 있음을 확인할 수 있다.

\section{4. 결 론}

이 연구에서는 건축물의 외장재로 널리 사용되고 있는 치장조적벽체에서 새롭게 개발한 연결철물 상세에 대한 내진성능을 실험적으로 평가한 결과 다음과 같은 결론을 얻었다.

(1) 연결철물을 설치한 모든 실험체가 국내건축기준에 의한 등가정적횡하중 $\left(F_{p}\right)$ 이상을 지지할 수 있으며, $2 \%$ 이상의 횡변위각 성능을 발휘하여 인명안전(LS) 의 성능 수준을 만족하고 있음을 확인하였다.

(2) 수직 록킹 바가 외벽조적벽체의 내진성능을 향상시키 는 결과를 나타내었고, 그 크기는 $3 \mathrm{~mm}$ 로 하는 것이 경제적인 측면에서 바람직하다. 또한 연결철물의 배치 는 엇모배치보다는 정렬배치로 하는 것이 바람직하다.

\section{감사의 글}

본 논문은 중소벤처기업부에서 지원하는 2017년도 산학 연협력 기술개발사업(No.C0564001)의 연구수행으로 인한 결과물임을 밝힙니다.

\section{References}

BIA (Brick Industry Association). (2013). Wall ties for brick masonry. Technical Notes on Brick Construction 44B, The Brick Industry Association.

FEMA (Federal Emergency Management Agency). (1997). NEHRP Guidelines for the Seismic Rehabilitation of Buildings. FEMA Publication 273, Washigton, D.C.

Jin, H.J., Han, S.W., Park, Y.M., and Lee, J.H. (2008). Seismic behavior of architectural masonry walls. Journal of the Architectural Institute of Korea, Structure \& Construction, Vol. 24, No. 7, pp. 45-52.

KS L 5105. (2007). Testing method for compressive strength of hydraulic cement mortar. Korea Standard Association

KS L 4201. (2017). Clay brick. Korea Standard Association

KS L 5220. (2018). Dry ready mixed cement mortar. Korea Standard Association

Martins, A., Vasconcelos, G., and Campos Costa, A. (2017). Brick masonry veneer walls: An overview. Journal of Building Engineering, Vol. 9, pp. 29-41.

MOLIT (Ministry of Land, Infrastructure and Transport). (2016) Korea Building Code (KBC) 2016.

Park, B.T., and Kwon, K.H. (2015). An experimental study 
on strength and ductility of masonry buildings retrofitted by metal connectors. Journal of the Korea Institute for Structural Maintenance and Inspection, Vol. 19, No. 3, pp. 113-121.

Yi, W.H., Lee, J.H., Kang, D.E., and Yang, W.J. (2004). An experimental study of material characteristics of brick masonry. Journal of the Architectural Institute of Korea, Structure \& Construction, Vol. 20, No. 12, pp. $45-52$.

\begin{tabular}{|l|l|}
\hline Received & October 24, 2018 \\
\hline Revised & October 25, 2018 \\
\hline Accepted & November 12, 2018 \\
\hline
\end{tabular}

